\title{
أخطاء الدارسين فى استخدام الكلمات المترادفة
}

\author{
سيف الرحمة فانغابيان \\ مدرسة إنسان تشينديكيا الثانوية الإسلامية الحكومية بتفانولى الجنوبية \\ syairhan@yahoo.com
}

\begin{abstract}
الملخصص
تمدف الدراسة إلى التعرف على الأخطاء اللغوية التي يقع فيها الدارسون في استخدام الكلمات المترافة. وأجرت الدراسة بمدرسة إنسان تيشنديكيا الثانوية الإسلامية الحكومية بتفانولى الجنوبية بسومطرا الشمالية ( MAN (Insan Cendekia Tapanuli Selatan أسلوب تحليل الأخطاء. وأخذ الباحث ع ع دارسا كعينة الدراسة. وبعد أن تمت الدراسة وأظهرت نتائجه أخطاء الدارسين اللغوية في استخدام الكلمات المترادفة كما يلي: (1) المبالغة في التعميم (ب) الجهال بقيود القاعدة (r) الأخطاء المستحجرة (ع) العوامل النفسية كالنسيان والتسرع والتعب والقلق والكسلان والمرض وما أشبه ذلك بك بكي
\end{abstract}

كلمات مفتاحية: الأخطاء، الترادف

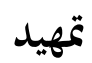

إن للغة العربية مكانة خاصة بين لغات العالم حيث أهـا لغة العرب والمسلمين وإحدى اللغات العالمية الرسمية التي تستخدمها هيئة الأمم المتحدة ويستخدمها كثير من الناس للاتصال والتفاهم بينهم، وفوق كل ذلك أها أداة لفهم الآيات القرآنية والأحاديث النبوية والكتب الإسلامية المكتوبة بها. ولذلك نجد أن هذه اللغة دورها هام في حياة المسلمين خاصة وغيرهم من الناس في العالم عامة. ولاتساع استخدام اللغة العربية في العالم العربي واحتكاك العرب بغيرهم، تزداد كلمات عربية ترجع إلى

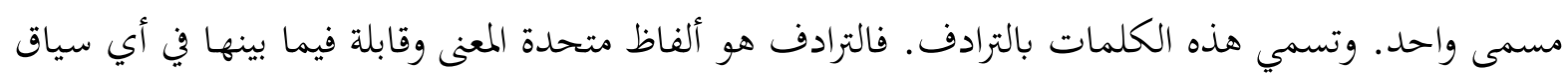
(التواب، 999 1). واللفظظ المترادف قـد يرادف لفظا مـن نوعـه كمرادفة الاسم للاسم والفعـل للفعـل والحـرف للحرف وقد يرادف لفظ من غير نوعه كمرادفة أسماء الأفعال للأفعال الدالة على معناها، نحو "شتان لبعد". ولا يرادف فعل اسما ولا يرادف فعل حرفا إلا نادر نحو كأنّ لفعل أشبّه وليت لأتمنى. وإلى جانب ذلك، أن الترادف لم يعتبر وجـوده بالنظر إلى علم اللغة الحقيقي حيث يكون لكل كلمـة

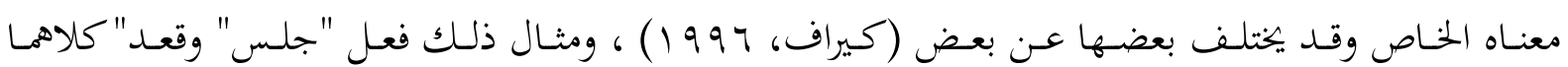
مترادفان، ولكن إن لاحظناهما من الناحية الدلالية فإهما مختلفان. يكون القعود للقائم والجلوس للنائم. 
وهكذا، إن الكلمة قد لا تحل مكان كلمة ترادفها في الجملة. ويرجع كل ذلك إلى عوامل ستة، هي

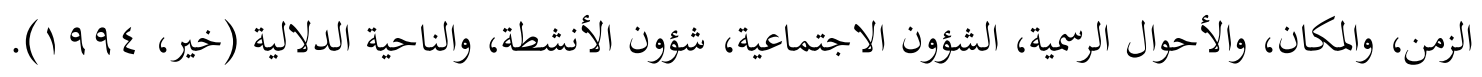

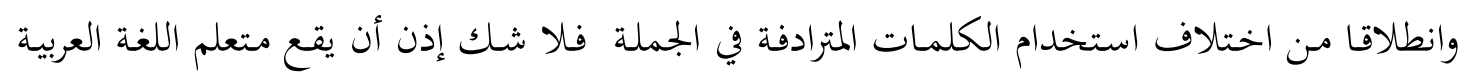

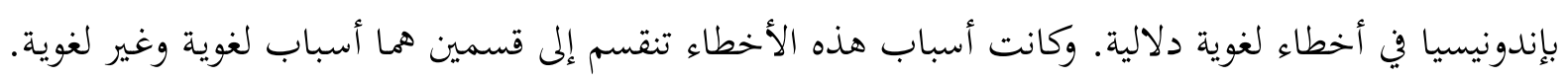

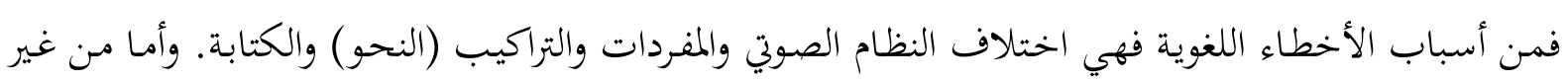
لغوية فهي اختلاف البيئة والعادات بين العربي والإندونيسي (الأمم، 1999 1). موضوع الدراسة واعتمادا على التمهيد فينحصر موضوع الدراسة على أنواع الأخطاء في استخدام الكلمات المترادفة

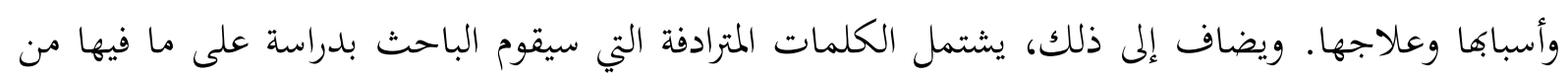

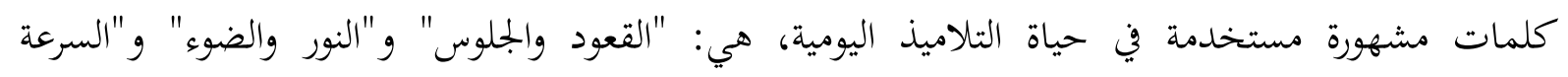

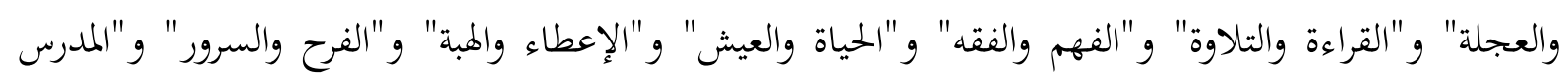

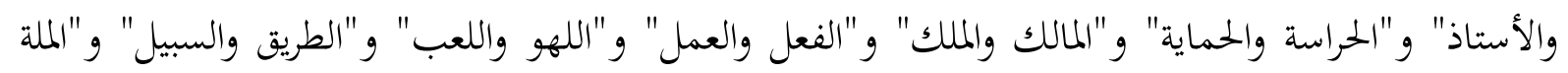

\section{منهج الدراسة \\ ا ـ منهج الدراسة ومكاها ومراحلها}

يستخدم في هذا البحث طريقة البحث الوصفي حيث تمدف هذه الطريقة إلى وصف الحقائق وأصافها

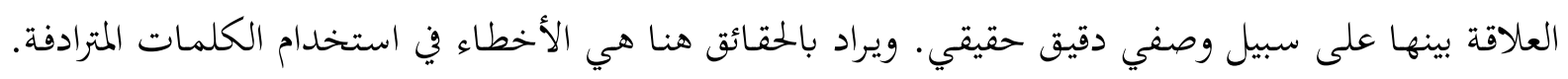

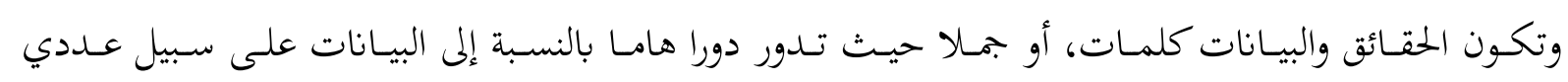
. (ناظر، (1999)

وإلى جانب ذلك، فإن الباحث يستخدم أيضا طريقـة البحث المكتبي وذلك للحصول على نظريات

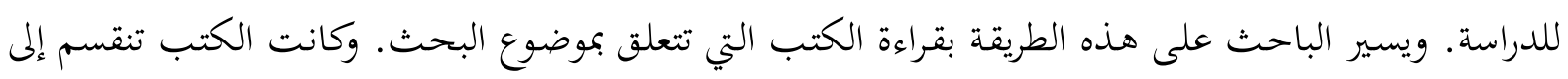

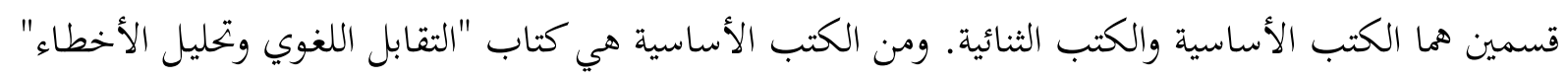
الذي ألفه إسماعيل صيني وكتاب "Error Analysis " الذي ألفه جاك ريتشارد وكتاب "الفروق اللغوية" الذي ألفي الفها أبو هلال العسكري.

وسيقوم الباحث بتنفيذ هذا البحث العلمي فن مدرسة إنسان تشينديكيا الثانوية الإسلامية الحكومية

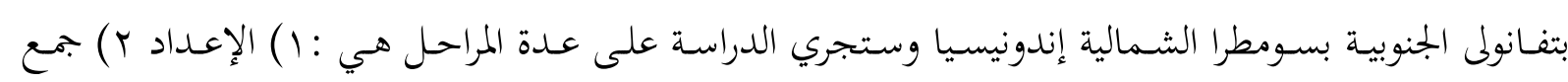
البيانات، r) تحليل البيانات، ع) كتابة الدراسة

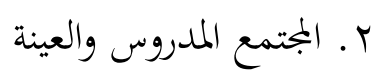


يشمل المجتمع المدروس لهذا البحث جميع دارسي الصف الثانى وبلغ عددهم ع ـ دارسا وأخذ الباحث

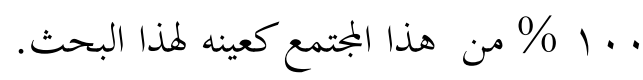

$$
\text { ع. أسلوب جمع الحقائق وتحليلها }
$$

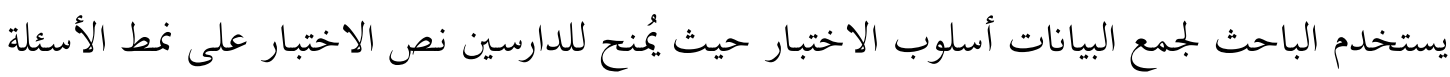

الاختيار من متعدّد ويقوم الباحث بعد ذلك بملاحظة الأجوبة ليعلم الأخطاء الموجودة فيها.

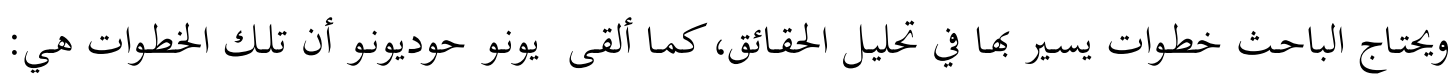

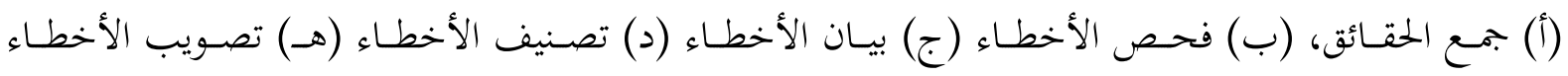

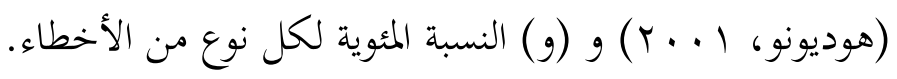

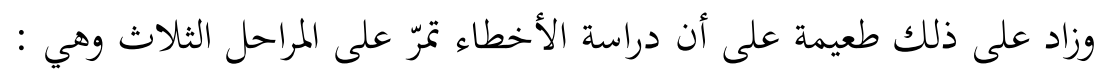

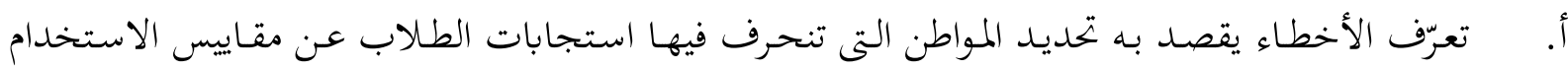

$$
\text { اللغوي الصحيح }
$$

ب. توصيف الخطأ، يقصد به بيان أوجه الانخرافات عن القاعدة وتصنيفه للفئة التى تنتمى إليها تحديد موقع الإع

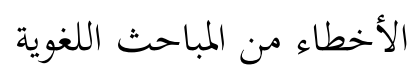

ج. تفسير الخطأ، يقصد به بيان العوامل التى أدت إلى هذا الخطأ والمصادر التى يعزي إليها (طعيمة، 919 1 )

\section{نظريات الدراسة}

\section{1 ـ مفهوم الترادف وأسباب وقوعه وفوالئه ائده}

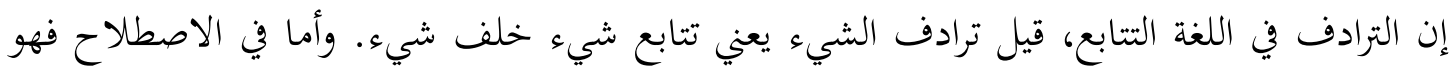

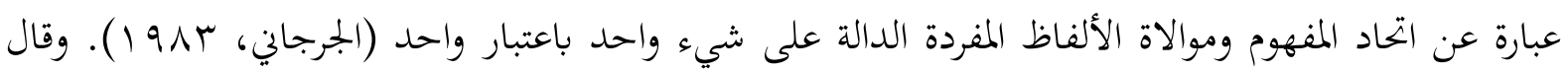

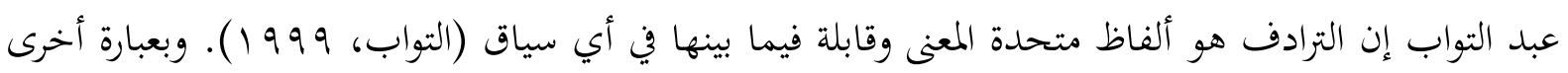

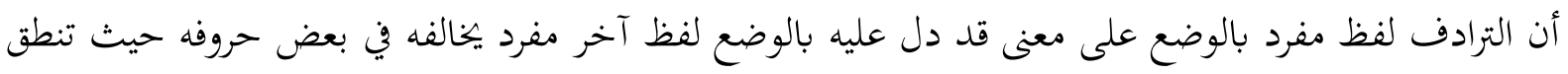
به قبائل العرب أي أنه ألفاظ مفردة يشترط استقلالها عند استعمالها في الدلالة.

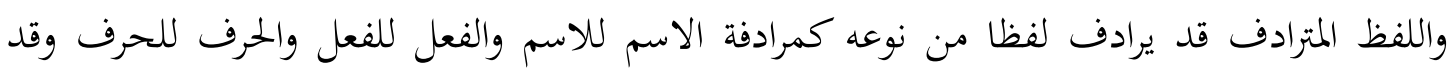

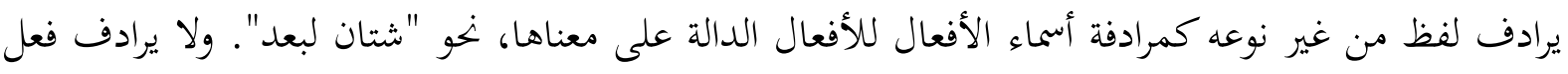

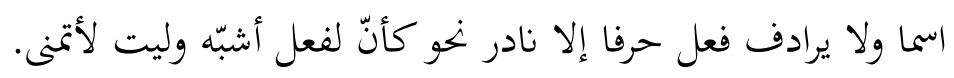

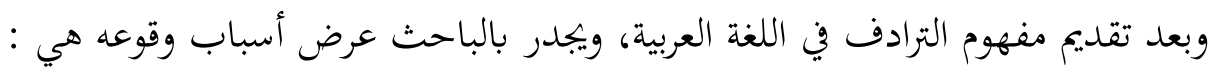

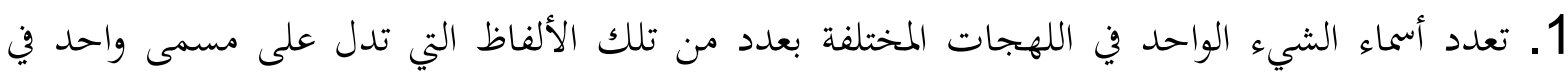
اللهجات المختلفة. 2. أن يكون للشيء الواحد في الأصل اسم واحد ثم يوصف بصفات مختلفة 
3. التطور اللغوي في اللفظة الواحدة، فقد تطور بعض أصوات الكلمة الواحدة على ألسنة الناس فتنشأ صور

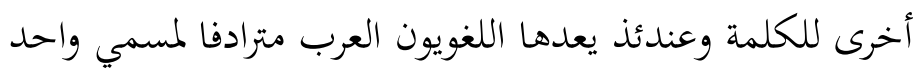

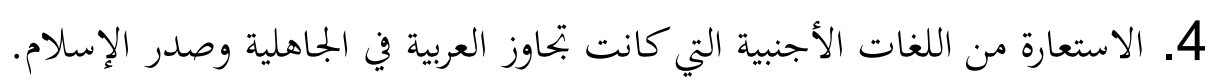

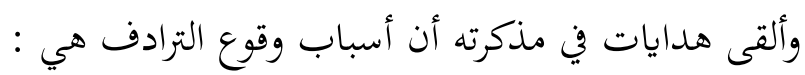

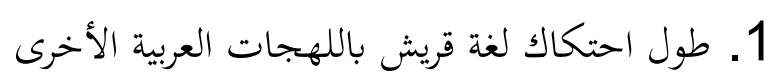

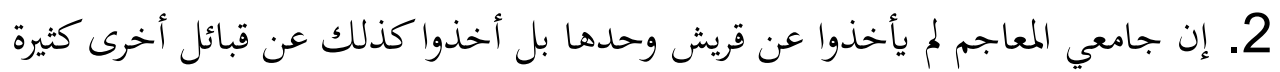

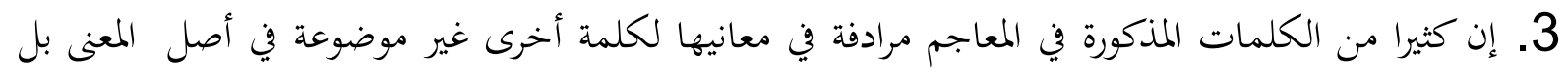
مستخدمة فيها استخداما بجازيا. 4. إن الأسماء الكثيرة التي يذكرها جامع المعاجم للشيء الواحد ليست جميعها. في الواقع أسماء بل معظمها صفات مستخدمة استخدام الأسماء

5. إن كثيرا من الألفاظ التي تعد مترادفة هي في الواقع ليست مترادفة بل يدل كل منها على حالة خاصة تختلف بعض الاختلاف على الحالة التي بدا عليها غيره.

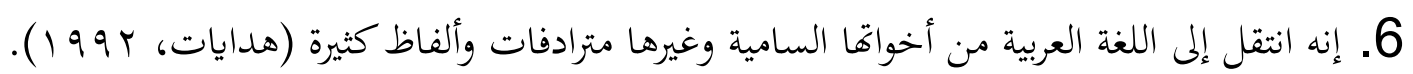

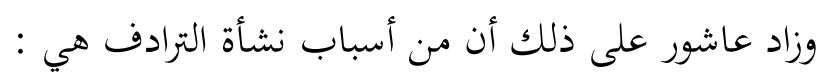
1. إن اللغة العربية قد تميزت عن أخواتها من اللغة السامية من حين التهاه اترادي هي انفصال العرب عن مواطن بقية الساميين

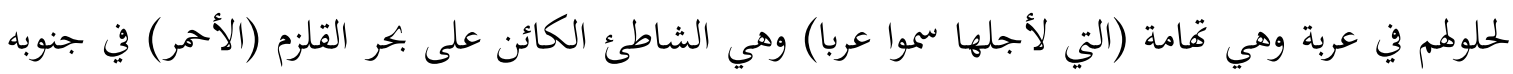

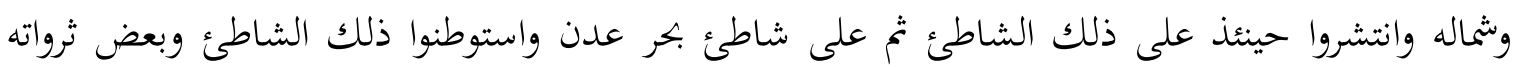

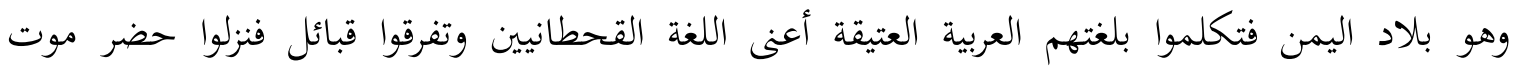

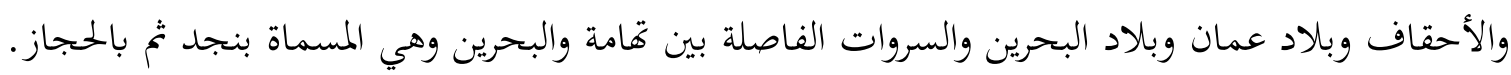
وكانت لغتهم متماثلة متقاربة إذ كانوا أمة واحدة. 2. اختلاف قبائل العرب في أسماء بعض الأشياء فتشيع الأسماء التي ينطقون بها كلها في جميع قبائلهم لا سيما في الحجاز لأها قرار القبائل. 3. اختلاف نطق قبائل العرب بغض الحروف مثل قولم "صراط" و "سراط" و "زراط".

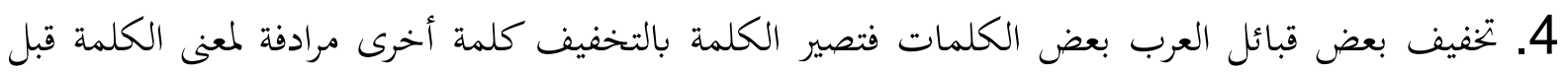
التخفيف مثل "كاك" بمعنى "كذلك" و "عاب" بمعنى "عيب". 5. ما دخل في لغات العرب من الألفاظ الأعجمية وهي ما يسمي بالمعرب مثل القسطاس من الرومية بمعنى العدل. 
6. كثرة المجاز في كلام شعراء العرب حتى يشيع شيوعا يقربه من الحقيقة فتحدث بسبب ذلك ألفاظ مرادفة في

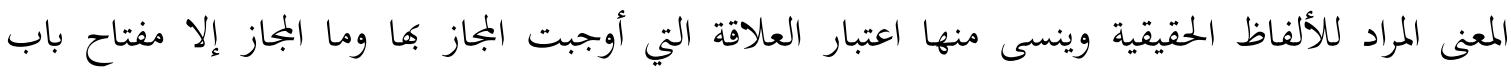

7. التوسع في الاستعمال واشتهاره، فمن ذلك إطلاق الوصف المشهور بدون ذكر الموصوف نهو إطلاق المدام

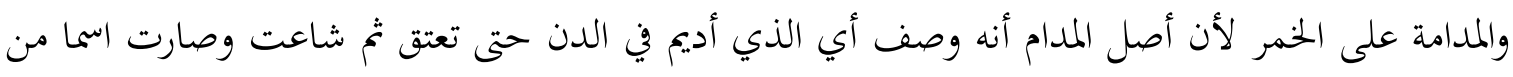

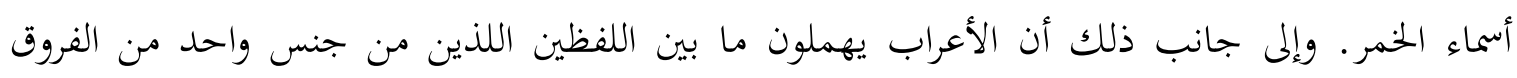

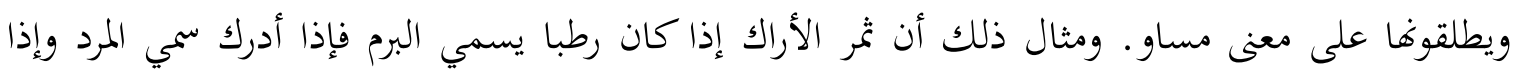
اسودّ سمي البرير فإذا يبس سمي الكباث.

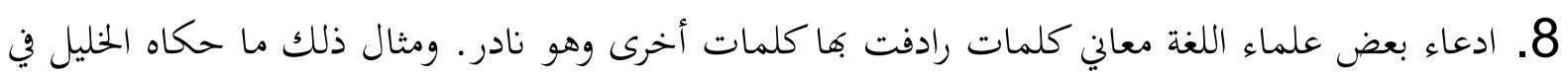

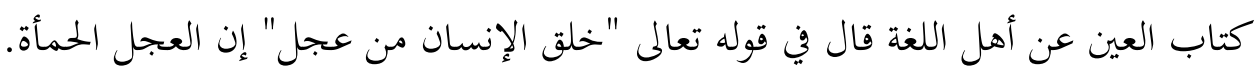

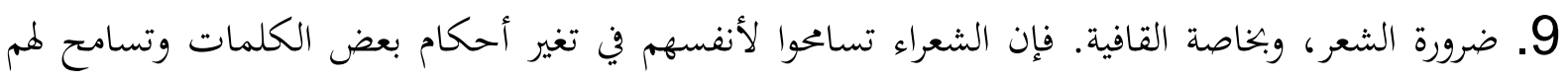

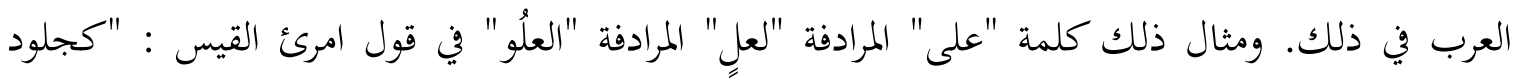
ضخر حطه السيل من عل".

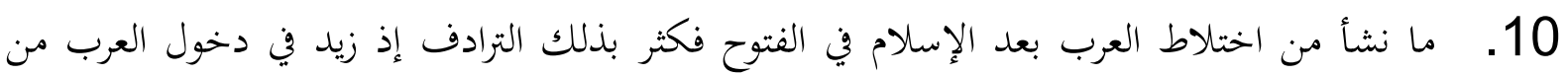

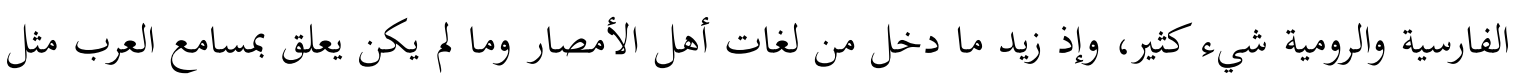

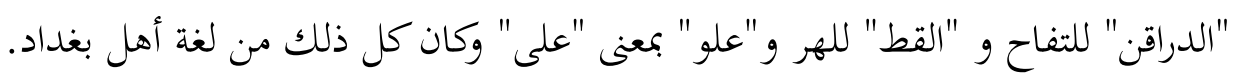

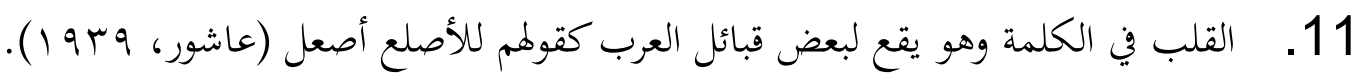

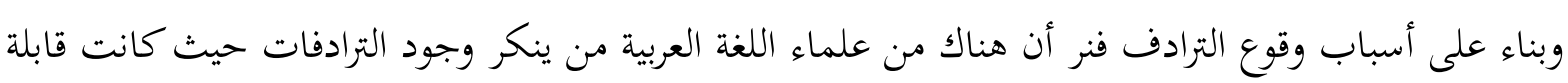

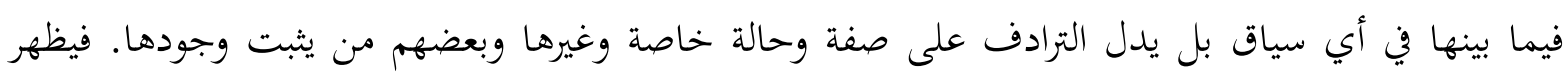

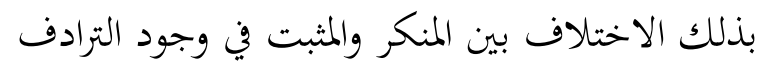

$$
\text { ومن فوائد الترادف على ما يلي : لمنين }
$$

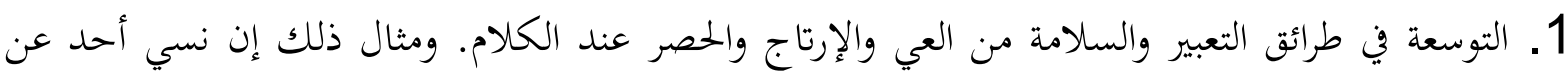

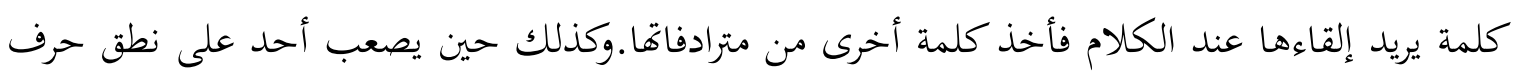

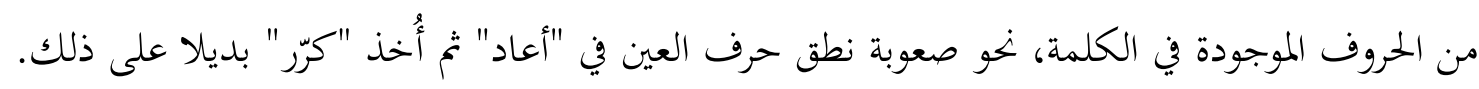

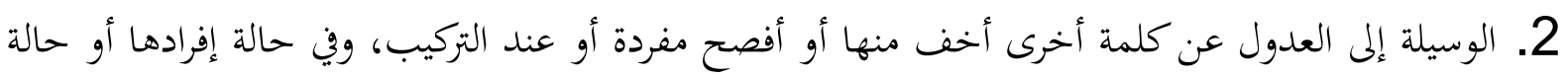

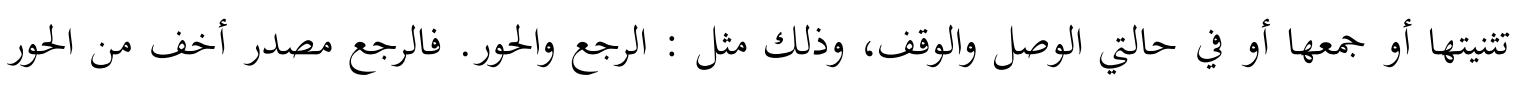

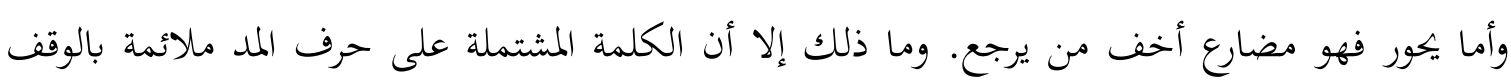

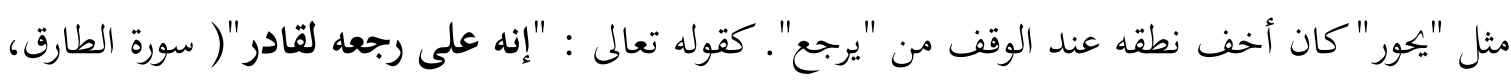

$$
\text { الآية: م) و و"إنه ظن أن لن يحور"( سورة الانشقاق، الآية : ع ( ). }
$$




\section{r. تعريف الأخطاء اللغوية.}

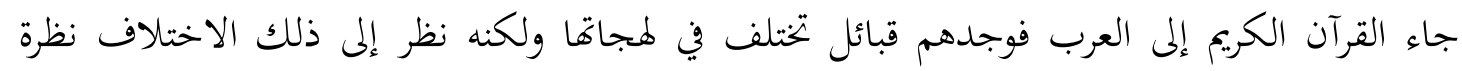

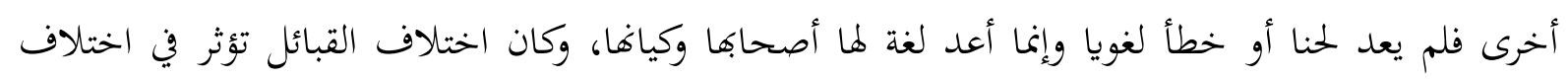

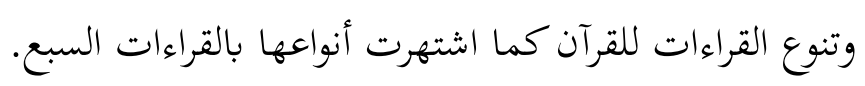

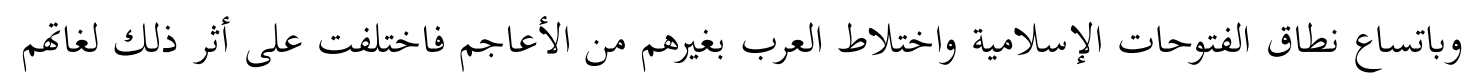
وظهر ما يعد عيبا ولحنا وخطأ في اللغة بل الفساد فيها سواء أكانت تحريرية أم شفهية.

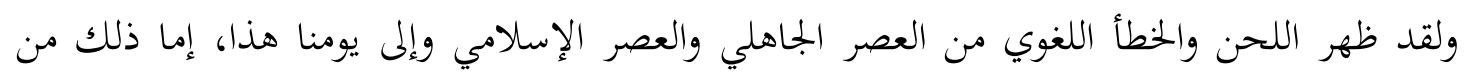

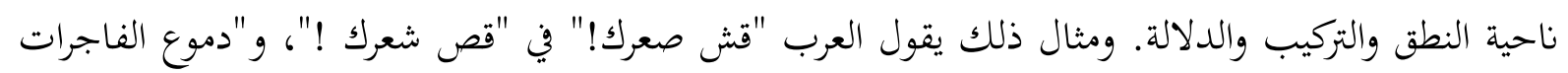

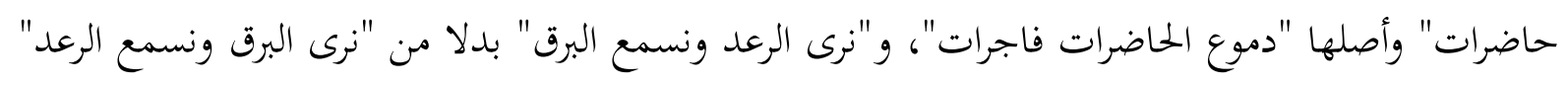

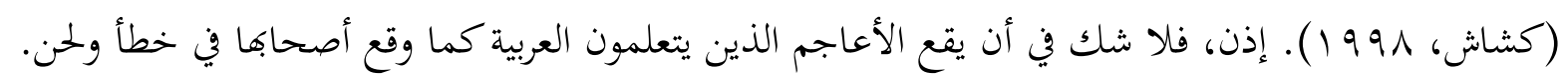

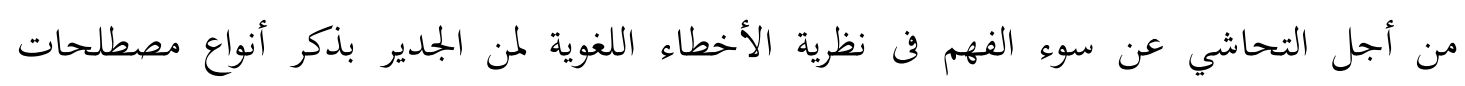

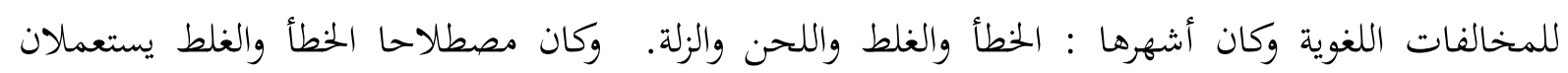
للدلالة على الانخراف اللغوي في مجال تعليم اللغات الاجنبية. أولا : تعريف الخطأ والغلط واللحن والزلة لغة الغة الغناق

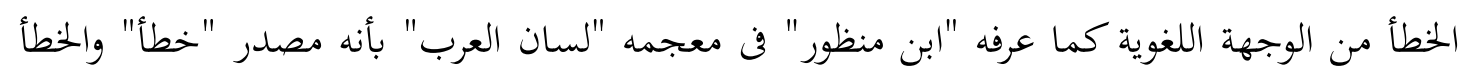

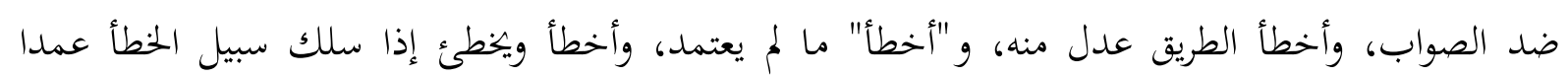

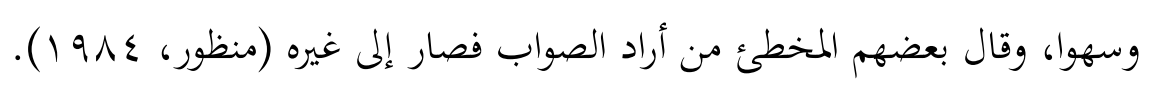

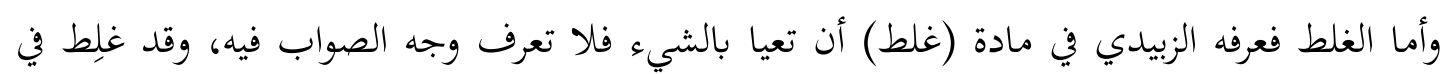

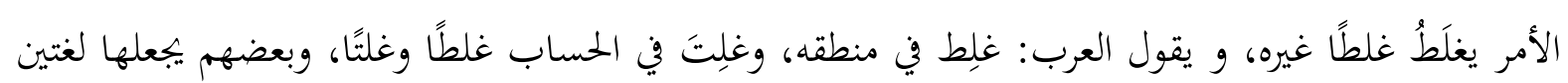

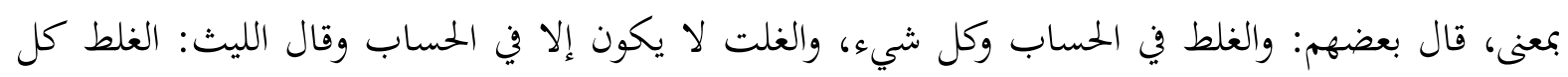

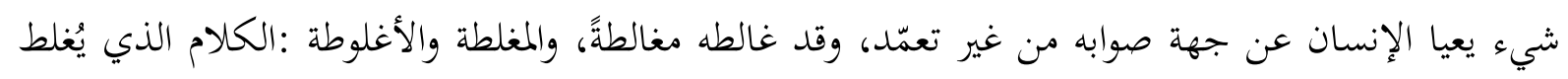
فيه (الزبيدي، بو 199 ). وإلى جانب ذلك قال ابن جنى فن الخصائص كان أبو علي يقول: إنما دخل الغلط فن كلامهم لأغم

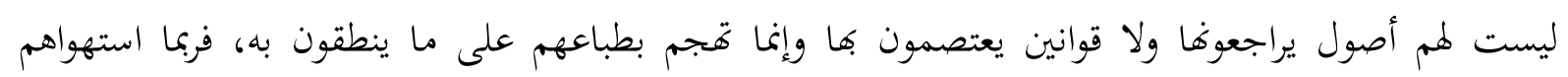
الشيء فزاغوا به عن القصد (جنى، r. r. r).

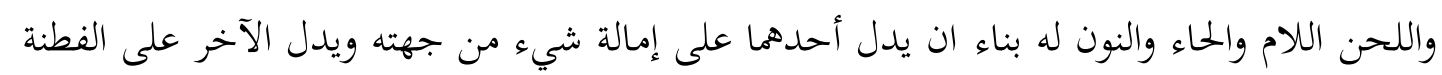

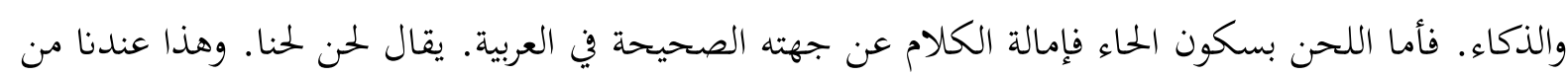


الكلام المولد لأن اللحن محدث لم يكن في العرب العاربة الذين تكلموا بطباعهم السليمة. وعرف صاحب

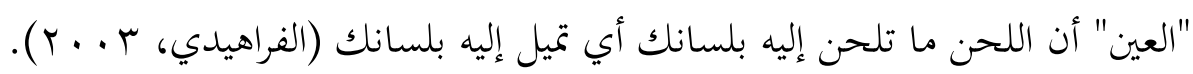

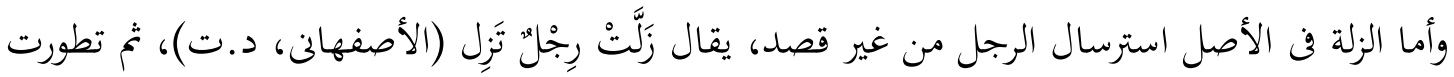

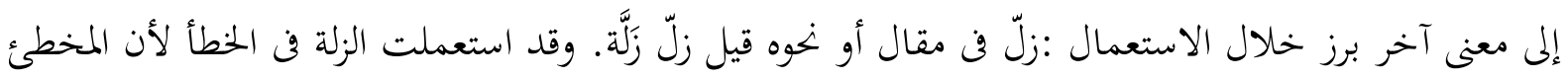

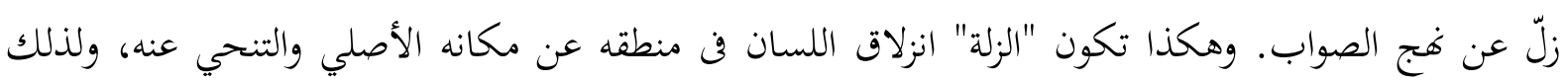

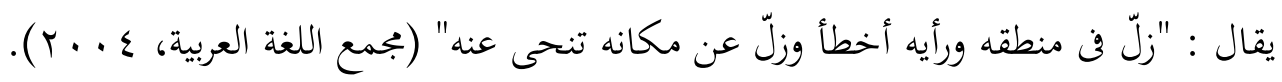

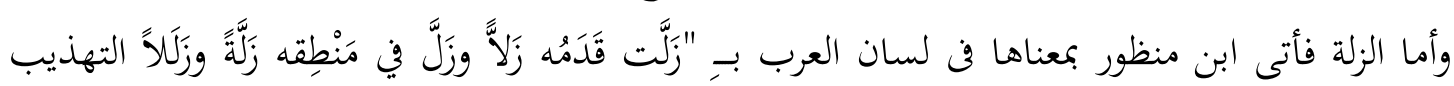

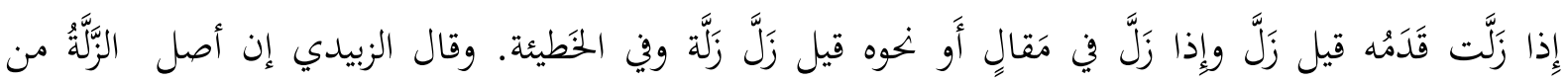

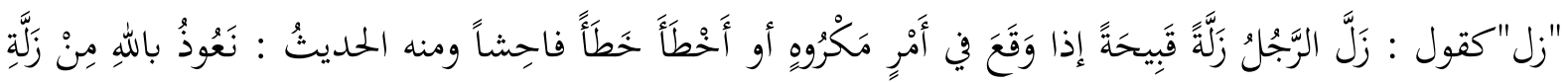

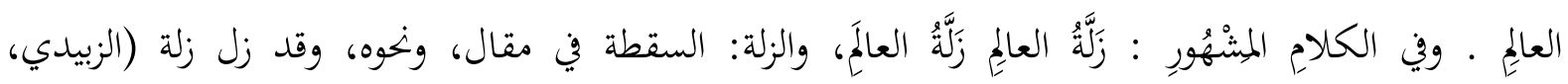

\section{ثانبا : تعريف الحطأ والغلط اصطلاحا}

اختلف اللّغيون حول تحديد مصطلح واحد للإنخراف اللغوي الذي يظهر على ألسنة وفي كتابات

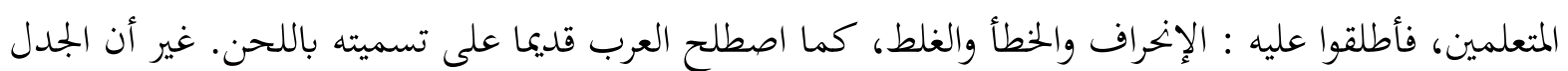

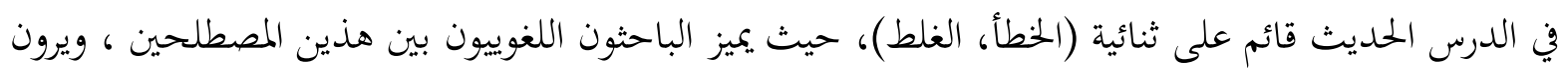

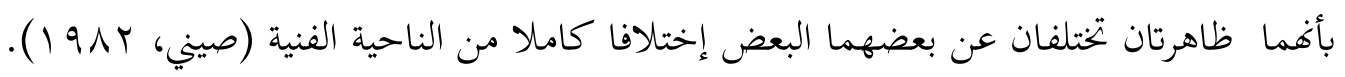

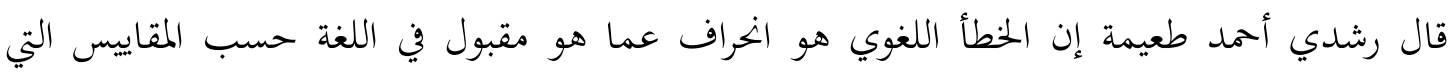

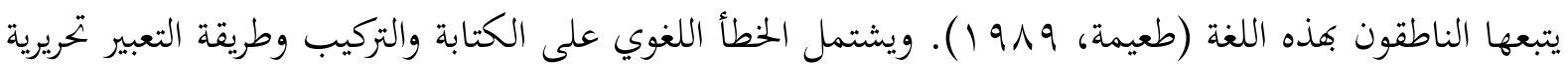
كانت أم شفوية وكل ما يتعلق بحضارة صاحب اللغة.

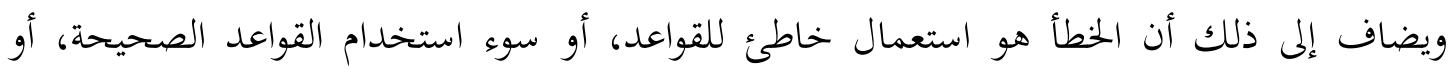

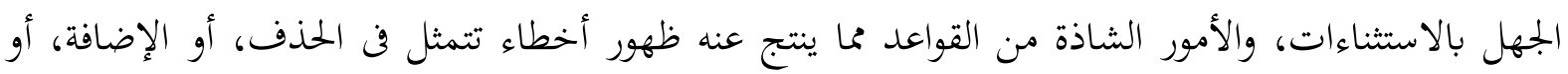

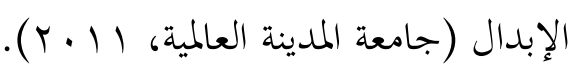

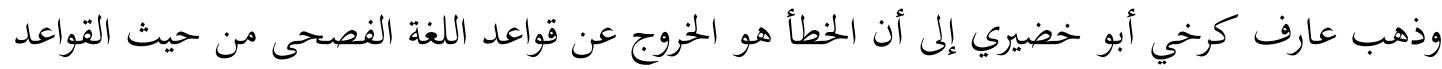

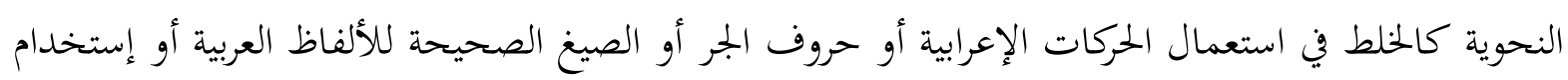

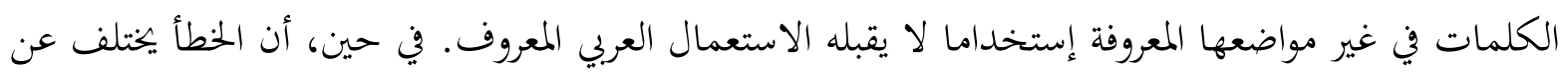

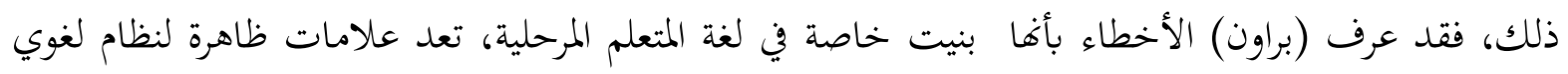

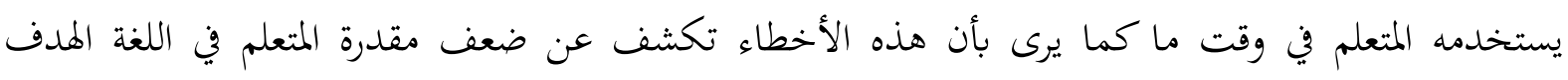

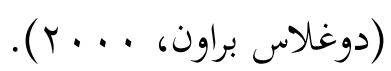


وأما الغلط كما رأته نابابان (Nababan، ع 99 ( ) فعلى أنه الانحراف عن قواعد اللغة ومواقفها الذى

$$
\text { يؤديه الأمور النفسية (الأيسكولوجية). }
$$

فمصطلح الغلط يشير إلى خطإ في الأداء اللغوي للمتكلم، وهذه الأغلاط قد تصدر عن المتكلمّين الأصليين باللغة، وبالتالي هي ليست نابحة عن ضعف مقدرة أو معرفة المتكلم بنظام لغته، بل هي نابحة عن نقصان عارض يتخلّل عملية إنتاج الكلام وذلك كالتردّد، أو زلة اللّسان، أو غيرها من هفوات الأداء اللغوي، وأهم ميزة لمذه الأغلاط أها قابلة للتصحيح، كما يمكن تصنيفها بوصفها أخطاء في نقل الموضع أو التبديل أو لو إضافة صوت. وقد أطلق براجا (Baradja، . 99 (1) على أن الأغلاط نابحة عن الأداء اللغوي مصطلح الأخطاء غير النظامية" Nonsystematic Errors"، في حين أطلق على الأخطاء النابتحة عن المقدرة اللغوية مصطلح الأخطاء

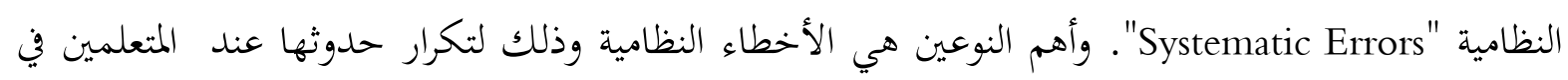
مستويات اللغة المختلفة إما بسبب جهل المتعلم للقاعدة وإما بسبب التداخل اللغوي وأغلبه في اللغة الثانية، وأما الأخطاء غير النظامية فتحدث في اللغة الأولى والثانية ومسبباته لا تكون ثابتة. ويمكن أن تزول بزوال مسبباتا العارضة وبواسطة المتعلم نفسه

ويرى اللغويون بأن التمييز بين أغلاط المتعلم وأخطائه ليس أمرا يسيرا ويتسم بالذاتية، مما يجعل الباحثين يقعون في افتراضات خاطئة ـوهو ما يؤكده قول إسماعيل صيني: "وقد لا يسهل دائما تمييز تلك الهفوات والزلات

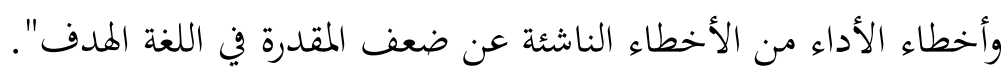
وخلاصة مّّا سبق، أن الأغلاط هي إنحراف عن قواعد اللغة ناتج عن زلة لسان أو هفوة وتكثر في مواقف التردّد أو التوتر أو الإرهاق، وبالتالي هي إخراف عارض في لغة المتعلم، في حين أن الأخطاء هي إخراف عن النظام الصحيح لقواعد اللغة الهدف، والصفة المميزة لهذه الأخطاء أفها متكرة، وتكرارها يدل على خلل في النظام اللغوي الذي رسخ في ذهن المتعلم، ولذلك اعتبرها الباحثون أكثر خطورة من غيرها وخصّوها بالدراسة والتحليل، وهذه الأخطاء و الإخرافات التي تظهر على ألسنة الدارسين، تكون في جميع مستويات اللغة إما الصوتي والصرفي والنحوي(التركبي) والدلالي.

ويلي جدول يبيّن الفروق بين الأخطاء والأغلاط (تاريغان، 99 1 ):

$$
\text { الجمدول الأول }
$$

\begin{tabular}{|c|c|c|c|}
\hline الأغلاط & الأخطاء & من ناحية التصنيف & 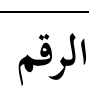 \\
\hline الأداء & القدرة & المصدر & 1 \\
\hline غير المنظمة & المنظمة & الصفة & r \\
\hline المدة القصيرة & المدة الطويلة & 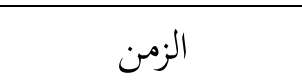 & $r$ \\
\hline
\end{tabular}

الفروق بين الأخطاء والأغلاط 


\begin{tabular}{|c|c|c|c|}
\hline وجود المعرفة & عدم المعرفة & النظم & $\varepsilon$ \\
\hline التحريف & التحريف & النتيجة & 0 \\
\hline التصحيح من التلميذ بالتركيز & التصحيح من المدرس بالتدريبات وغيرها & التقويم & 7 \\
\hline
\end{tabular}

ثالثا : تعريف اللحن والزلة اصطلاحا

اللحن في اصطلاح علماء اللغة يرجع أيضًا إلى المعني العام الذي ذُكر من قبل وهو إمالة الشيء عن وجهته . واللحن بمعني الخطأ فهو أظهر اصطلاحًا لهذا اللفظ. ظهر لفظ اللحن مبكرًا ، لا كما زعم بعضهم متأخرا. فقول الرسول صلى الله عليه وسلم: "أنا أعرب العرب ولدت فن قريش ونشأت في بني سعد فأني يأتيني اللحن"(السيوطي، 1910 1) ، ثم حديث أبى الأسود

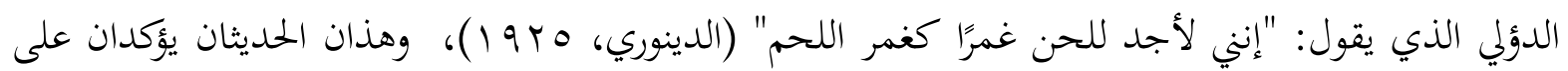
قدم اللحن. والذين يزعمون بتأخير اللحن ، يذكرون أن التاريخ لم يعرف اللحن عند العرب بمعني مخالفة التعبير الصحيح ، قبل أن يختلط هؤلاء بالأعاجم · و يأخذون في التفرقة بين فصاحة المنطق وفساد اللسان، فاللحن لم يكتسب هذا المدلول الخاص ، إلا في وقت متأخر، بعد أن تعارف الناس على تغييرمعناه اللغوي الأصلي الذي هو أسلوب التعبير أو طريقته فكيف يستعمله الرسول إليه صلوات الله عليه بمعني الخطأ؟ فيما نسبوا في قوله السابق، فلفظ اللحن هنا شاذ وغير منسجم السياق ومؤكد أن الذين أدرجوه في الحديث هيابون من اللحن مأخوذون بسحر الأعراب، فلا سبيل في أن يسلم هذا الحديث من النقد إذا أصر المحتجون به ، أن يجعلوا اللحن فيه مرادفًا للخروج عن قواعد الإعراب ، لأن العرب في عهد الرسول وضعوا لهذا اللحن كنهًا مثل الرثة واللفة

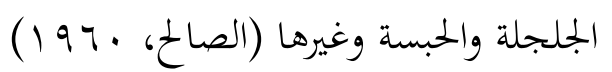

يرى الباحث أن مدلول لفظ اللحن قد تأخر عن الدلالات الأخرى، ولكن لمن المعلوم أن الرسول لا يخاطب الناس إلا بما يفهمونه ، ولو أفم يعلمون أن يأتي بمعني الخطأ في الاستعمال لرحلوا عنه لغيره ـويختلف اللحن عن عيوب النطق، فقد تكون عيوب خلقية ، أو نتيجة لتأثير اللهجة على العببة الفصحى، أو غير ذلك لك من العيوب

فمدلول اللحن نشأ عن اتفاق عرفي بين عرب البادية فقد كان لهم ذوق مرهف، وإحساس صادق بجمال اللفظ المنطوق، كما عرفوا أيضًا العوائق الحسية والنفسية التي تعترض النطق، ولاحظوا خصائص اللهجات واللغات الخاصة. لكنهم لمم يعرفوا كنها للخطأ في القواعد والخروج على النحو. أما اللفظ القديم للحن الذي يطلقه علماء اللغة والنحو اصطلاحًا على الخطأ في اللغة ما اكتسب هذا المدلول نتيجة لاتفاق عريف على تغيير معناه. 
وذكر عبد العزيز مطر أن اللحن هو الخطأ فن اللغة أصواتها أو نهوها أو صرفها أو معانى مفرداتها.

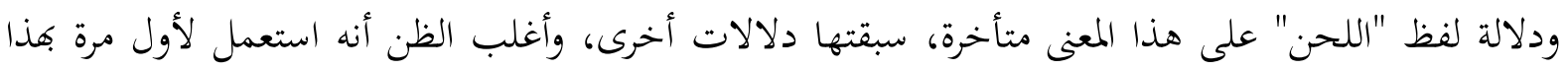

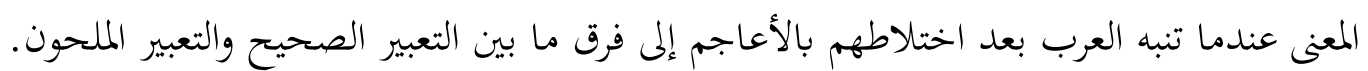

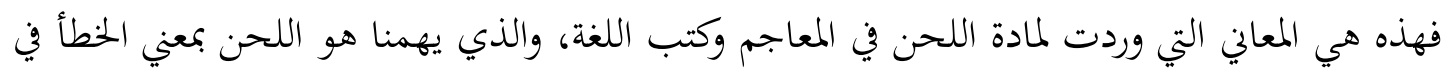

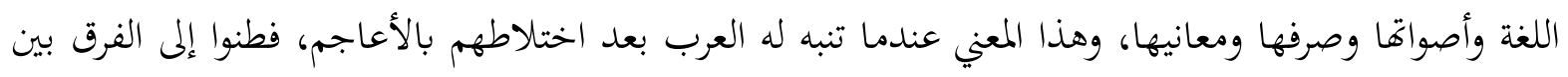

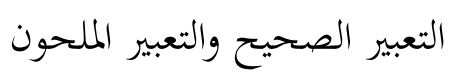
وهنالك من فرق بين الخطأ واللحن ، فيقولون أن الخطأ ينطبق على تغيير كلمة بكلمة أخرى ، أو تقديم

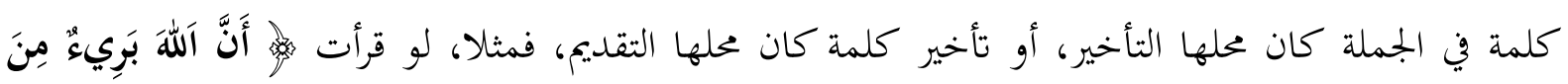

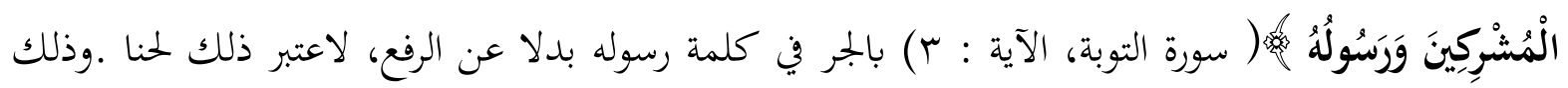

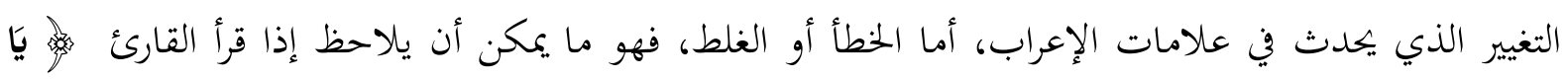

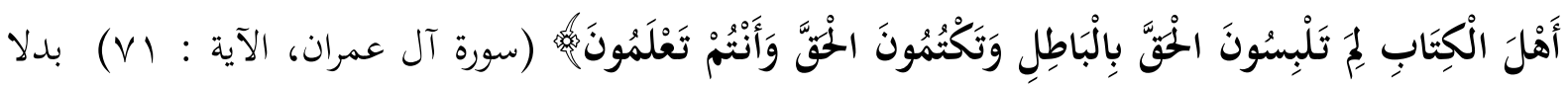

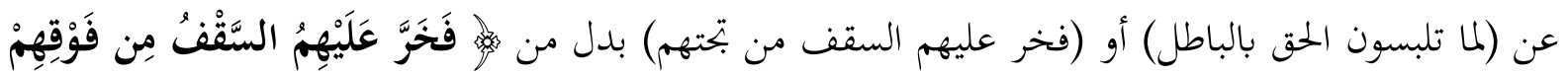

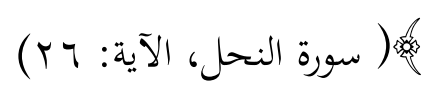
وهكذا، من المثال السابق يُستنتج على أن الخطأ كان تغيير يحدث في الكلمة أو الجملة لا يترتب عليه

$$
\text { تغيير أو فساد في علامات الإعراب }
$$

إذ أن كل لحن خطأ وليس كل خطأ لحنا. و والمقصود باللحن في هذاب الكلام هو: خروج الكلام الفاب الفصيح

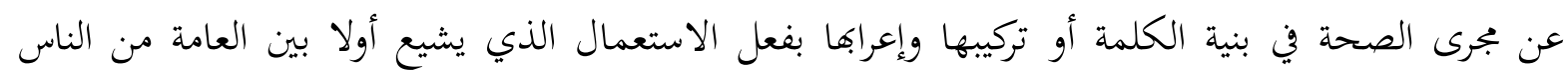

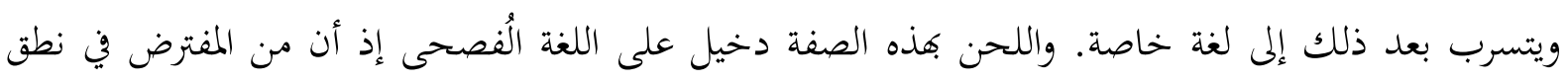

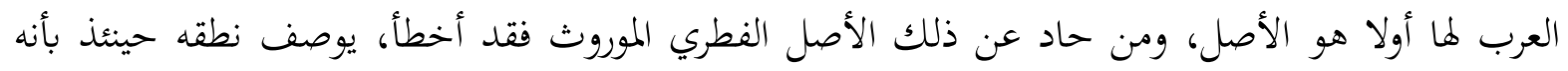

وأما الزلة فهي الأخطاء بسبب تحويل الناطق طريقه للتعبير عن شيء قبل تكملة جميع العبارات وكان

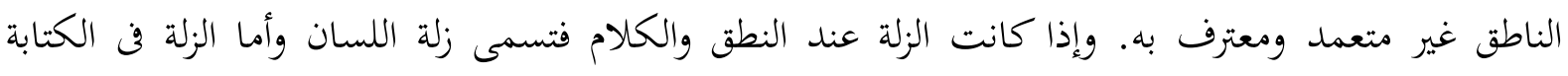

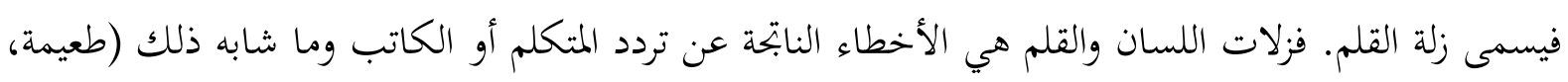

ويضيف أبو الرب بقوله:يقصد بـالزلة هي الاخطاء التي تصدر عن النسيان والسهو، لا عن الجهل

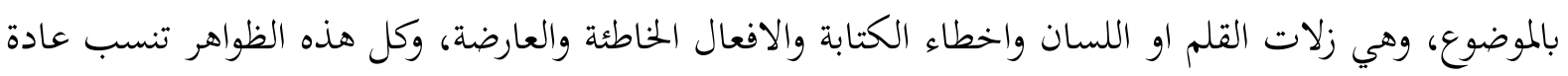

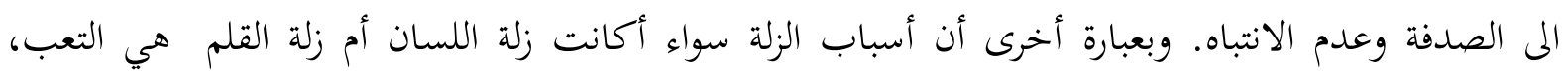

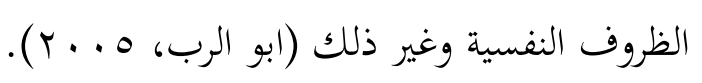


وبعد أن قام الباحث بتصويب جواب تلاميذ الفصل الثانى مدرسة إنسان تشينديكيا الثانوية الإسلامية

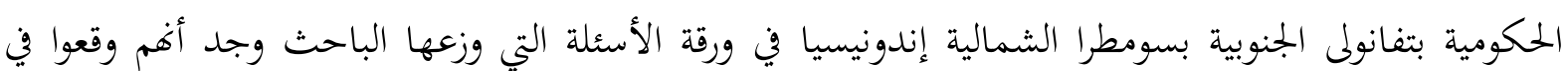
أخطاء عند استخدامهم الترادف. وسيأتي جدول لتوضيح عدد التلاميذ الخاطئين حسب رقم الأسئلة : الجمدول الثاني

بمموع التلاميذ الخاطئين

\begin{tabular}{|c|c|c|}
\hline النسبة المئوية & جموع التلاميذ الخاطئين & رقم الأسئلة \\
\hline$\% \vee$. & $\mu_{1}$ & 1 \\
\hline$\% \circ$. & Tr & r \\
\hline$\% 11$ & 0 & r \\
\hline$\% \leq 0$ & $r$. & $\varepsilon$ \\
\hline \% & $r \wedge$ & 0 \\
\hline$\% r v$ & Ir & 7 \\
\hline \% ד & $r q$ & V \\
\hline$\%$ rq & IV & $\Lambda$ \\
\hline$\% r V$ & Ir & 9 \\
\hline$\%$ & $r q$ & 1. \\
\hline$\%$ Vr & MT & 11 \\
\hline$\%$ or & rr & $1 T$ \\
\hline$\%$ & $r \varepsilon$ & $1 T$ \\
\hline$\% \leq 0$ & $r$. & $1 \varepsilon$ \\
\hline$\% \wedge \uparrow$ & ऍᄉ & 10 \\
\hline
\end{tabular}

وظهر لنا من الجدول السابق أن التلاميذ لا يزالون خاطئين في استخدام الكلمات المترادفة مع أها كلمات شائعة عندهم. ب. تحليل البيانات

بعد وصف الباحث عدد التلاميذ الخاطئين في استخدام الترادف، يود أن يحلل تلك البيانات تفصيليا حسب رقم الأسئلة وذلك للحصول على أسباب تلك الأخطاء ولسهولة الاستنتاج ومحاولات لحلها. 1. الخطأ في استخدام فعلي "يقعد ويجلس" لجملة "دخل أحمد الفصل ثم...على الكرسي. وقع اب تلميذا (أي • . 


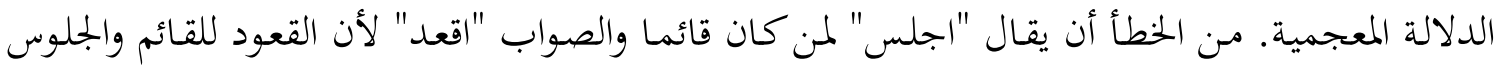

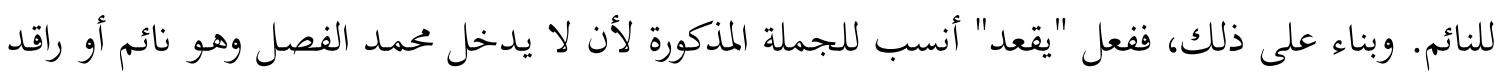
بل ماشي وقائم.

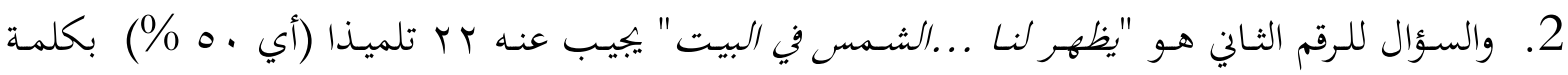

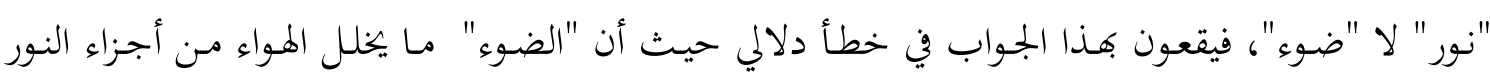

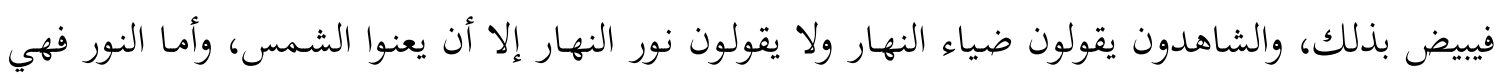

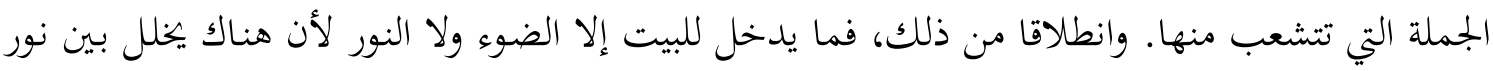
الشمس وما يظهر في البيت.

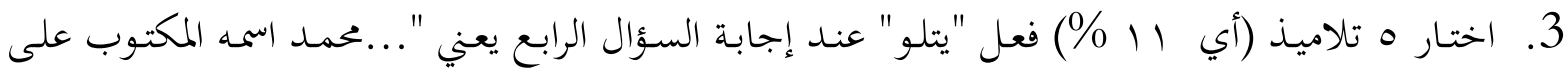

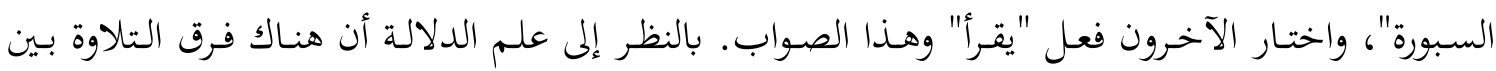

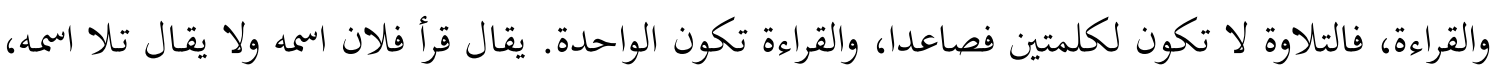

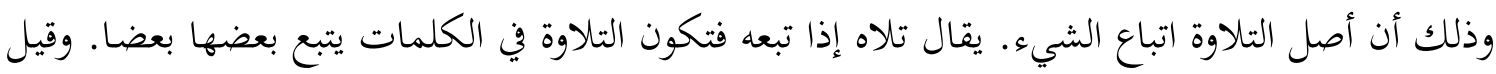
أن التلاوة القراءة دون الفهم والقراءة وجود الفهم.

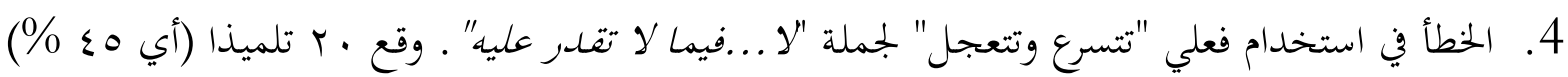

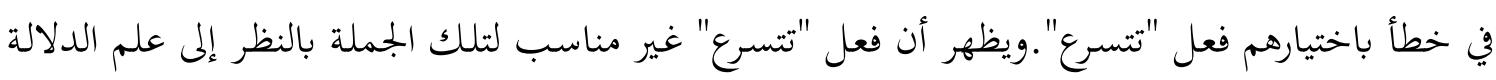

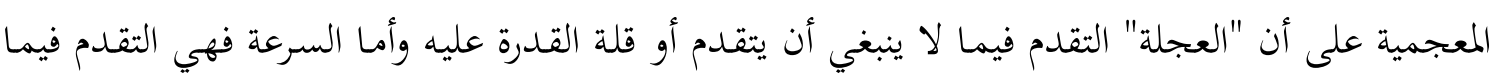

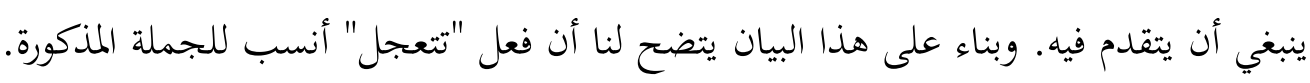

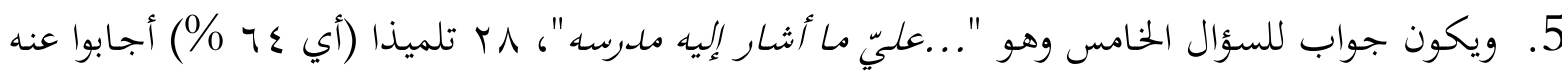

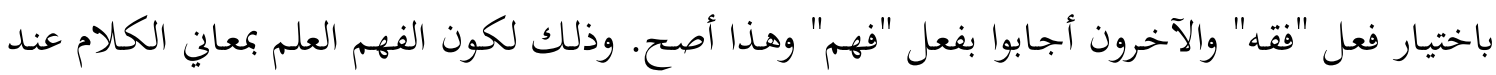

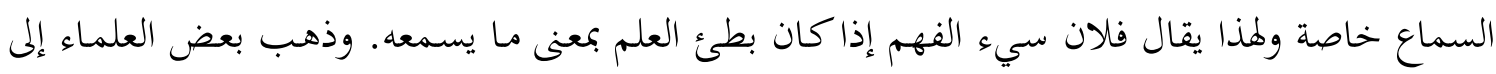

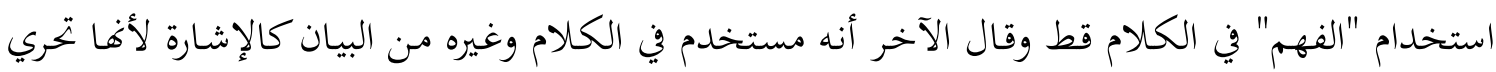

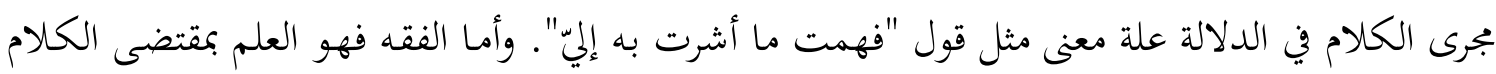

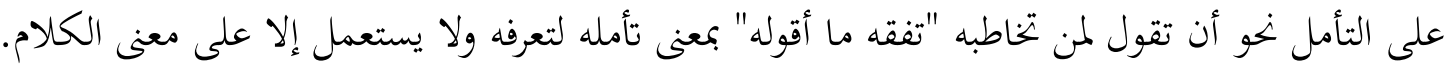

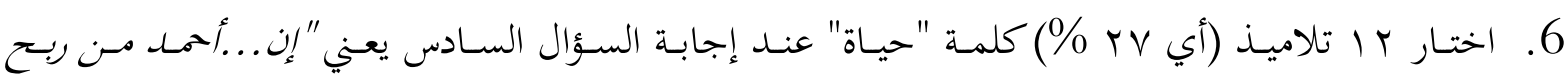

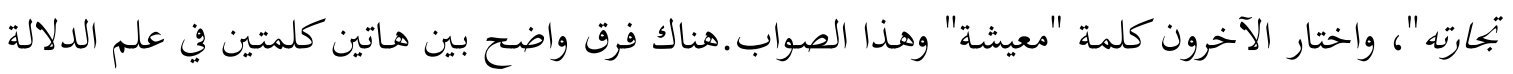

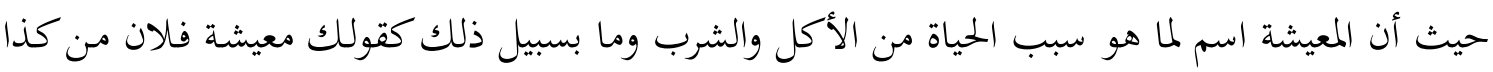

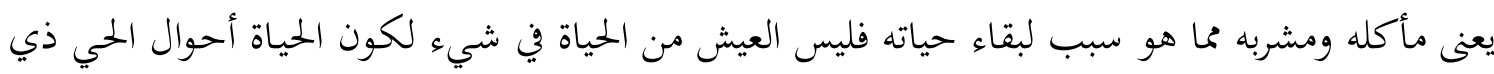
روح وجسم وجنس ويقع على الواحد والجمع. 


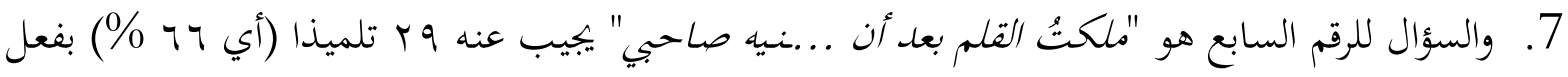

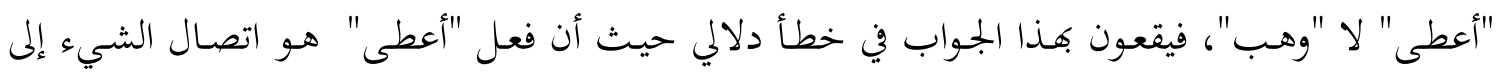

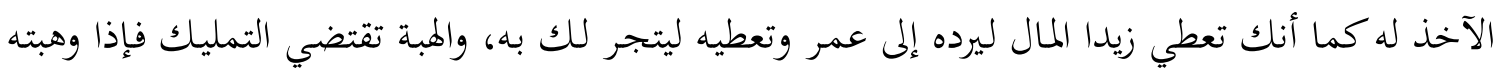
له فقد ملكته إياه.

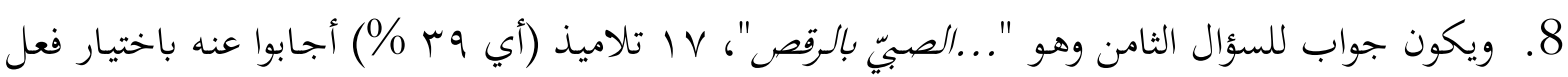

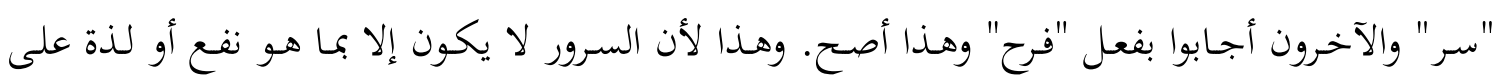
الحقيقة، وقد يكون الفرح بما ليس بنفع ولا لذة كفرح الصبي بالرقص والسباحة وغير ذلك الك منا يتبعه ويؤذيه. وكان نقيض السرور الحزن والفرح الغم.

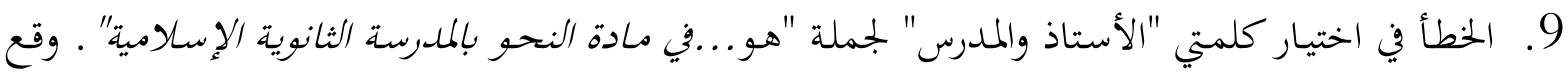

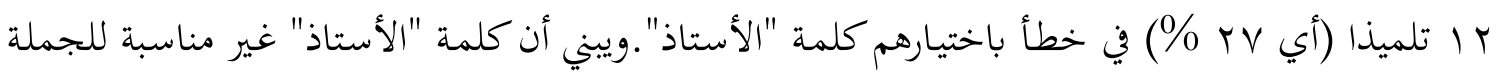

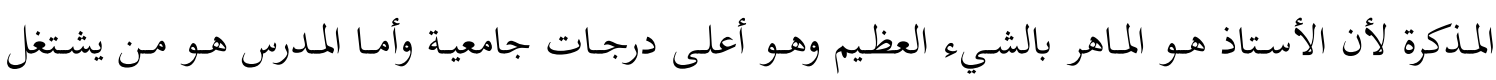

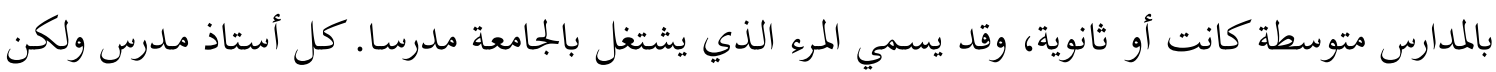
ليس مدرس أستاذا.

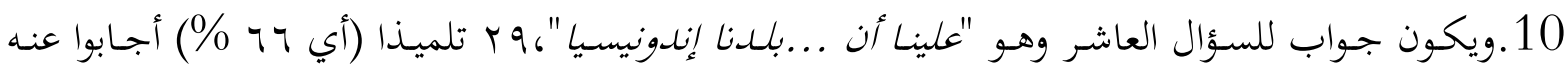

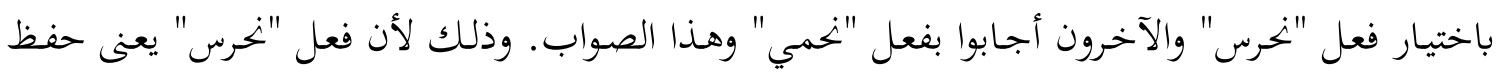

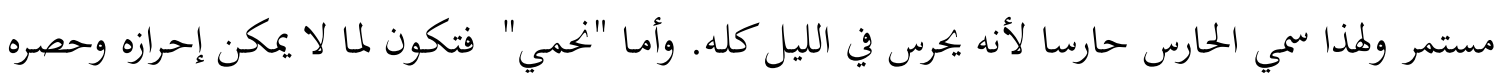
مثل الأرض والبلد ويقال هو يحمي الأرض.

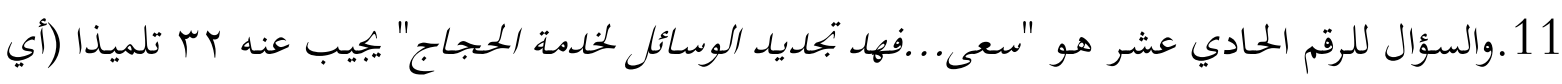

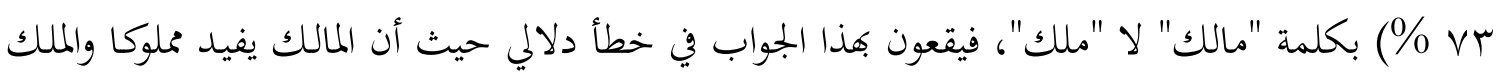

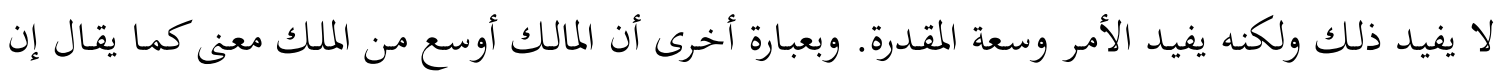

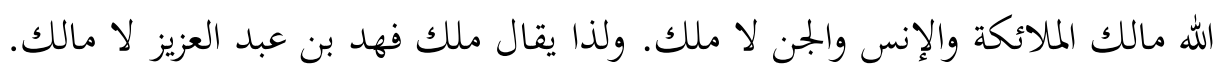

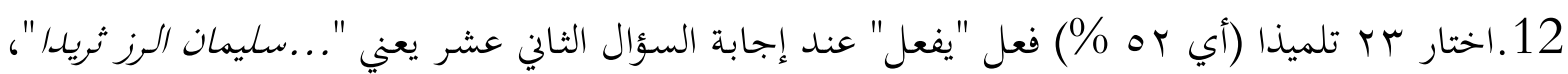

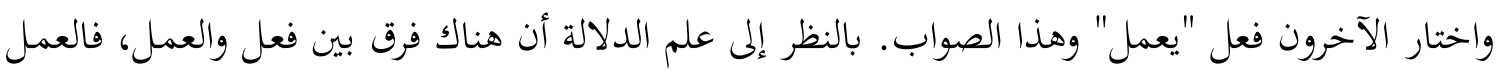

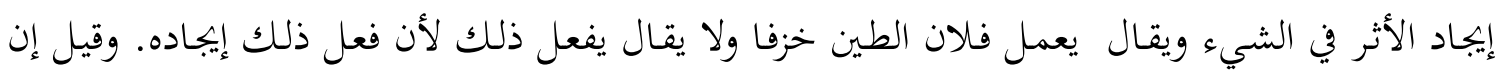

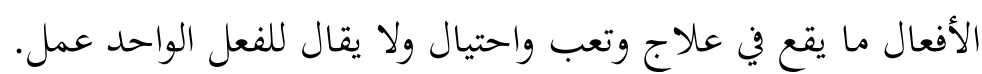

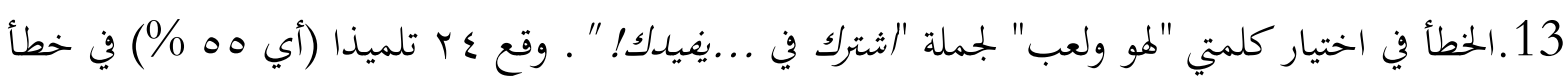

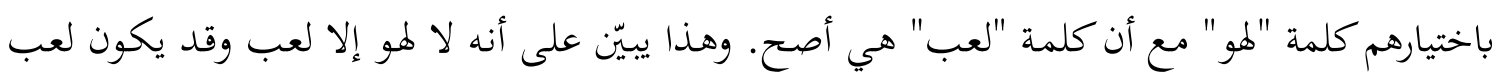

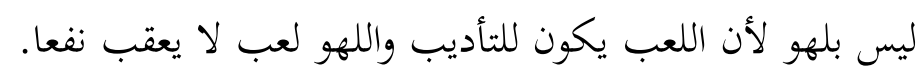


14.ويكون جواب للسؤال الرابع عشر وهو "إن التعلم والاجتهاد كلاهما ...إلى النجاح والنسلاح"، . ب تلميذا (أي 0ء \%) أجـابوا عنـه باختيـار كلمـة "طريقتـان" والآخـوون أجـابوا بكلمـة "سبيلان" وهـذا أصـح، لأن الطريق ما لا يقتضي السهولة والسبيل اسم على ما يقع عليه الطريق وعلى ما لا يقع عليه الطريق كقول

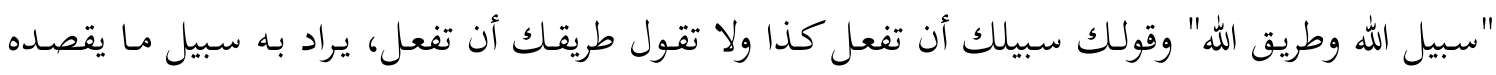
فيضاف إلى القاصد ويراد به القصد.

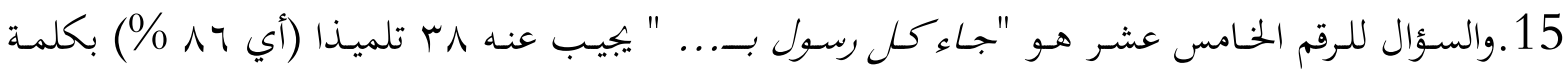
"ديـن" لا "ملـة"، فيقعون هـذا الجمواب في خطأ دلالي حيث أن الملة اسم للشـرائع مع الإقرار بالله، وأمـا الدين فهو اسم لما عليه كل واحد من أهله. كما يقال فلان حسن الدين ولا يقال حسن الملة وإنما يقال هو من أهل الملة. وأن كل ملة دين وليس كل دين ملة واليهودية ملة لأن فيها شرائع وليس الشرك ملة.

وبعد وصف أنواع أخطاء التلاميذ وتحليلها ظهر لنا أن الأخطاء التي يكثر فيها التلاميذ وقوعا هي الخطأ

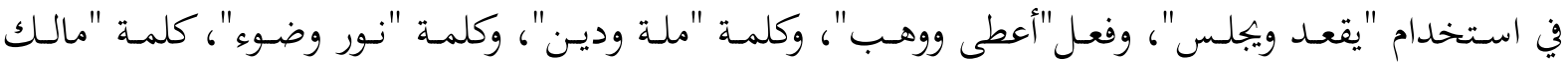

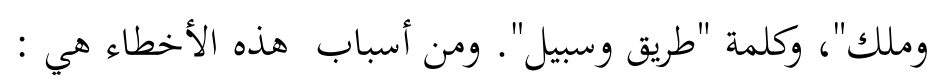
1. المبالغة في التعميم (over generalization) حيث أن التلاميذ يبسطون معنى الكلمتين المترادفتين ويعممونه، نهو "جلس" و "قعد".

2. الجهل بقيود القاعدة، حيث أفهم لم يتعلموا علم الدلالة العربية، ولذا فلا شك أن يقعوا في الخطأ اللغوي. 3. الأخطاء المستحجرة (Fossilized Errors) حيث أن هذه الأخطاء وقعت جيلا بعد جيل زمنا بعد زمن ولا يكاد الناس يعترفون أغها خطأ، نحو كلمة "أستاذ" عند الإندونيسي وكذلك عند العرب. 4. العوامل النفسية كالنسيان والتسرع والتعب والقلق والكسلان والمرض وما أشبه ذلك. وكانت أسباب الأخطاء المذكورة مـن أسباب الأخطاء اللغوية التطورية حيث يحاول الطلاب استخدام اللغة العربية خلال تعلمها. وبعد معرفة هذه الأسباب ليطلب علاجها حتى لا يقع الطلاب في الأخطاء مرات عديدة.

وأما العلاج لتلك الأسباب فيمكن أن يخطو المدرس خطوات آتية : 1. شرح معاني المفردات مع بيان فرقها الذي يقوم به المدرسون خلال تدريسهم مادة ةغلالا العربية 2. أن يقوم المدرس بتصويب أخطاء التلاميذ خلال التدريس خاصة في استخدام الكلمات المترادفة مباشرة. 3. الإكثار من التدريبات الإنشائية التحريرية حيث يستخدم فيها الكلمات المترادفة أغلبية 4. الإكثار مـ قراءة الكتب العربية مع ملاحظة فرق الكلمات المترادفة المستخدمة فيها لينمو ذوق التلاميذ اللغوي ويعلمون أية كلمة أنسب للجملة. 
5. أن يكون هناك درس الدلالة إن أمكن، متكامل للدروس العربية الأخرى.

\section{قائمة المراجع}

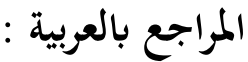

الأصفهاني، الراغب ، المفردات في غريب القرآن. (د.ت). بيروت: دار المعرفة

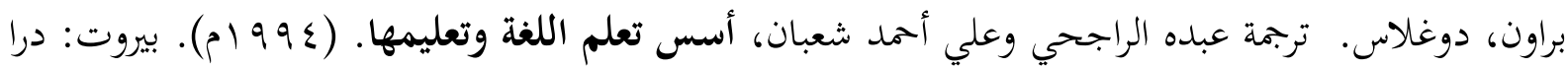

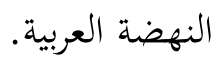

التواب ،رمضان عبد. (999 ام) فصول في فقه اللغةز القاهرة: مكتبة الخانجي

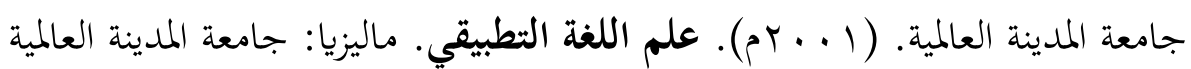

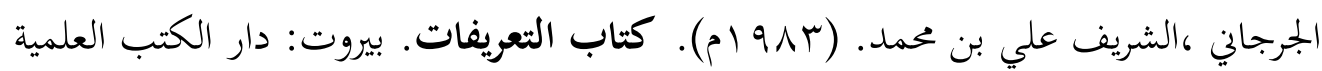
د. هدايات. (199T) مذكرة فقه اللغة. جاكرتا: قسم اللغة العربية لكلية التربية جامعة شريف هداية الله الإسلامية الحكومية

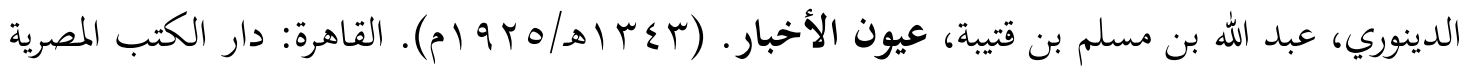

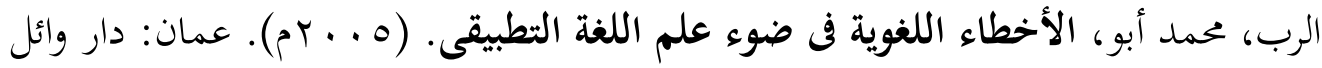

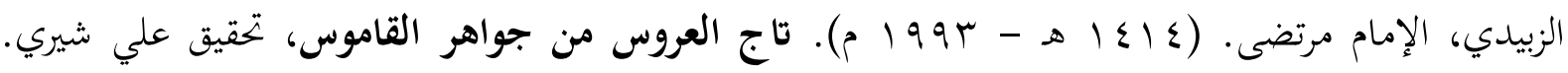
بيروت: دار الفكر

السيوطي، أبو الفضل جلال الدين عبد الرممن أبي بكر ،الحصائص الكبرى. (0. ــ اهـ/919 ام). بيروت: دار الكتب العلمية.

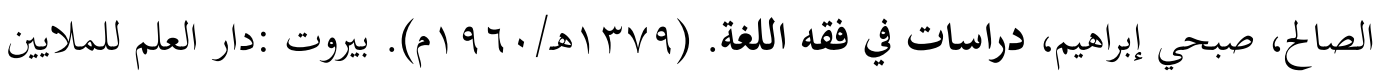

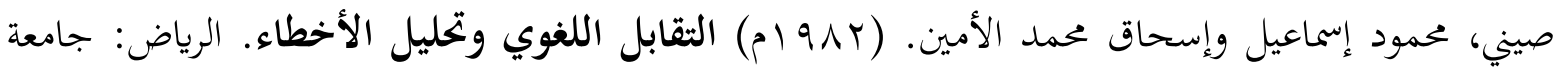

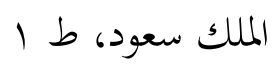

طعيمة، رشدي أحمد. (919 ام) تعليم اللغة العربية لغير الناطقين بما مناهجه وأساليبه. الرباط: إيسيسكو.

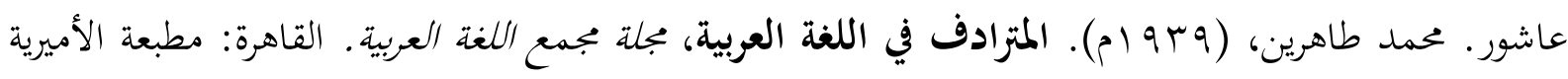

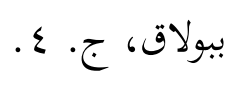

العسكري، أبو هلال. (د.ت) الفروق اللغوية. بيروت: دار الكتب العلمية

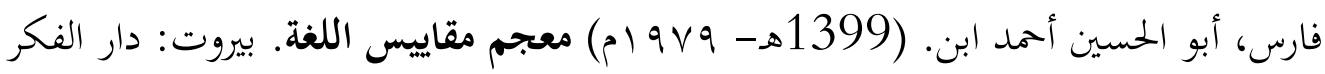

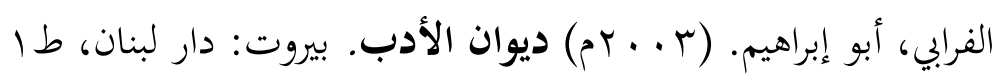

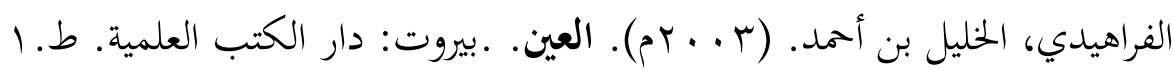




$$
\begin{aligned}
& \text { كشاش، محمد. (19 } 99 \text { (م)). علل اللسان وأمراض اللغة . بيروت: المكتبة العصرية }
\end{aligned}
$$

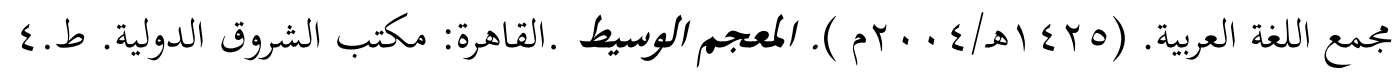

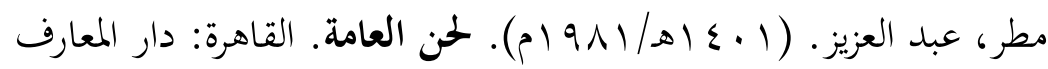

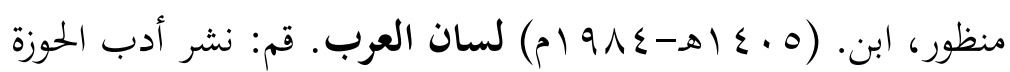

$$
\begin{aligned}
& \text { الهروي، أبو منصور محمد بن أحمد بن الأزهري، تحذيب اللغة، تحقيق: محمد عوض مرعب. ( ( . بم ). } \\
& \text { بيروت: دار إحياء التراث العربي . ط. }
\end{aligned}
$$$$
\text { المراجع بالانجليزية والاندونيسية : }
$$

Baradja, M.F.(1990). Kapita Selekta Pengajaran Bahasa. Malang: IKIP Malang

Chaer, Abdul. (1994). Linguistik Umum. Jakarta: Rineka Cipta

Douglas, H. Brown. (2000). Principles of Language Learning and Teaching. San Fransisco:

Longman.

Hudiono, Yono and Leo Idra Ardiana. (2001). Analisis Kesalahan Berbahasa. Jakarta: Universtitas Terbuka

Keraf, Gorys.(1996). Diksi dan Gaya Bahasa. Jakarta: Gramedia Pustaka

Nababan, Sri Utari Subyakto. (1994). Analisis Kontrastif dan Analisis Kesalahan : Suatu

Kajian dari Sudut Pandang Guru Bahasa. Jakarta: Program Pascasarjana Pendidikan Bahasa IKIP Jakarta

Nazir, Muhammad. (1999). Metode Peneltian .Jakarta: Ghalia Indonesia

Tarigan, Henry Guntur dan Djago Tarigan. (1990) Pengajaran Analisis Kesalahan Berbahasa . Bandung: Angkasa

Umam, Chatibul. (1999) 'Prolematika Pengajaran Bahasa Arab di Indonesia', Al-Turas

Nomor 08/1999. Jakarta: Fakultas Adab IAIN Jakarta 